\title{
PENGARUH STRATEGI BERSAING DAN ORIENTASI WIRAUSAHA \\ TERHADAP KINERJA PERUSAHAAN DENGAN LINGKUNGAN PERSAINGAN SEBAGAI VARIABEL MODERATOR (STUDI PADA PERUSAHAAN JASA LAUNDRY DI LABUHANBATU)
}

\author{
Zuriani Ritonga \\ Sekolah Tinggi Ilmu Ekonomi Labuhanbatu, Sumatera Utara - Indonesia \\ E-mail : zuriani2017@gmail.com
}

\begin{abstract}
ABSTRAK
Penelitian ini bertujuan untuk menganalisis pengaruh strategi bersaing dan orientasi wirausaha terhadap kinerja perusahaan serta pengaruh strategi bersaing terhadap kinerja perusahaan dengan lingkungan persaingan sebagai variable moderator pada perusahaan jasa laundry di Labuhanbatu. Populasi dalam penelitian ini adalah perusahaan jasa laundry di Labuhanbatu dengan teknik sampling yang digunakan sampling jenuh. Teknik analisis yang digunakan adalah moderator regression analysis. Dari hasil analisis menunjukkan bahwa ada pengaruh yang signifikan antara Strategi Bersaing dan Orientasi Wirausaha terhadap Kinerja Perusahaan sedangkan Lingkungan Persaingan bukan sebagai variable moderating yang mempengaruhi Strategi Bersaing dengan Kinerja Perusahaan pada Perusahaan jasa laundry di Labuhanbatu.
\end{abstract}

Kata kunci: Strategi bersaing, Orientasi Wirausaha, Lingkungan Persaingan, Kinerja Perusahaan

\section{PENDAHULUAN}

Di era modern saat ini, persaingan di berbagai sektor menjadi semakin ketat. Lingkungan bisnis menjadi semakin cepat berubah dan semakin sulit untuk diprediksi. Hal ini menyebabkan setiap perusahaan harus mampu merumuskan dan mengimplementasikan strategi pemasaran yang tepat, kompetitif, serta secara terus menerus menyesuaikan dengan lingkungan persaingan yang terus berubah agar supaya penjualan dapat dipertahankan atau ditingkatkan. Perusahaan harus merancang strategi untuk mencapai tujuannya, sehingga 
hasil yang diinginkan berupa daya saing dan profitabilitas yang tinggi dapat dicapai. Tanpa dukungan strategi yang tepat, perusahaan akan sulit untuk bertahan ditengah persaingan.

Persaingan bisnis yang semakin kompetitif menuntut perusahaan untuk menerapkan strategi bisnis yang tepat dalam menghadapi lingkungan bisnis yang turbulen, yang diindikasikan oleh proses inovasi secara terus menerus dan tingginya tingkat perubahan selera konsumen. Menurut Kathandaraman dan Wilson (2001), salah satu kunci sukses perusahaan dalam persaingan bisnis adalah memiliki dan mempertahankan keunggulan kompetitif yang terletak pada kemampuan perusahaan untuk membedakan diri dengan pesaingnya dan kemampuan produksi dengan biaya yang lebih rendah.

Tull dan Kahle dalam Tjiptono, (2009:6), menyatakan bahwa strategi pemasaran merupakan alat fundamental yang direncanakan untuk mencapai tujuan perusahaan dengan mengembangkan keunggulan bersaing yang berkesinambungan melalui pasar yang dimasuki dan program pemasaran yang digunakan untuk melayani pasar sasaran tersebut.

Persaingan yang terjadi sekarang ini sangat berbeda dari persaingan pada masa lalu sehingga strategi pemasaran perlu disesuaikan. Strategi pemasaran menjadi kunci kesuksesan perusahaan dalam era globalisasi, sementara orientasi wirausaha dipandang sebagai sebuah seni dalam melihat tantangan dan peluang yang sedang dihadapi. Orientasi wirausaha adalah kecenderungan organisasi untuk menerima proses, praktek, dan pengambilan keputusan entrepreneurial yang ditandai dengan preferensi terhadap innovativeness, risk taking (keberanian mengambil risiko) dan proactiveness.

Penerapan strategi, bertujuan untuk mencapai posisi yang menguntungkan dan kuat dalam menghadapi persaingan. Lingkungan dapat diarahkan untuk mengembangkan aksesbilitas terhadap peluang-peluang yang dihasilkan dan mengembangkan adaptibilitas terhadap ancaman- ancaman yang akan datang. Pengenalan lingkungan akan memberi dampak pada mutu strategi yang dihasilkan dan akan memberi dampak pada kinerja pemasaran. Kinerja akan ditentukan oleh seberapa baik kualitas input sumber daya maupun kualitas pengelolaan faktor-faktor lingkungan (Ferdinand, 2000). 
Banyak strategi yang dapat dilakukan oleh pemilik usaha jasa laundry ini untuk menarik minat dari konsumen. Salah satu strateginya adalah dengan menggunakan (empat P) Product, price, promotion, place Sedangkan yang dimaksud dengan lingkungan dalam makalah ini adalah lingkungan pemasaran yang terbagi menjadi dua yaitu lingkungan internal atau mikro dan lingkungan eksternal atau makro.

Kinerja pemasaran mertupakan faktor yang sangat umum untuk mengukur dampak dari sebuah strategi perusahaan. Pertumbuhan penjualan merupakan konsep untuk mengukur prestasi pasar suatu produk. Pertumbuhan penjualan merupakan sumber pertumbuhan pangsa pasar. Pertumbuhan penjualan digunakan untuk semua variabel peneliti sebagai salah satu variabel pembentuk kinerja pasar. Kinerja pasar sendiri merupakan bagian dari kinerja pemasaran (Mckee, et al, 1989 dalam Han, et al, 1998: 36 dan Permadi, 1998: 75).

Jasa laundry yang semakin banyak berkembang di Labuhanbatu memberikan dampak positif bagi masyarakat Labuhanbatu. Jasa laundry ini bukan hanya berdampak pada masyarakat yang menggunakan laundry tetapi dapat juga mengurangi pengangguran dan meningkatkan kesejahteraan masyarakat sekitar. Masyarakat Labuhanbatu sekarang lebih banyak yang bekerja sebagai pekerja kantoran sehingga dengan adanya jasa laundry dapat membantu pekerjaan rumah tangga menjadi lebih ringan. Dengan berkembangnya fenomena ini maka pemilik usaha jasa laundry akan membuat berbagai strategi pemasaran.

Dari latar belakang inilah peneliti tertarik untuk melakukan penelitian dengan judul "Pengaruh strategi bersaing dan orientasi wirausaha terhadap kinerja perusahaan dengan lingkungan persaingan sebagai variable moderator (studi pada perusahaan jasa laundry di Labuhanbatu".

\section{Perumusan Masalah}

Berdasarkan latar belakang maka masalah penelitian dapat dirumuskan sebagai berikut :

1. Apakah strategi bersaing berpengaruh terhadap kinerja perusahaan pada usaha jasa 
laundry di Labuhanbatu?

2. Apakah orientasi wirausaha berpengaruh terhadap kinerja perusahaan pada usaha jasa laundry di Labuhanbatu?

3. Apakah strategi bersaing dan orientasi wirausaha berpengaruh terhadap terhadap kinerja perusahaan pada usaha jasa laundry di Labuhanbatu dengan lingkungan persaingan sebagai variable moderator?

\section{Tujuan Penelitian}

Berdasarkan rumusan masalah yang digunakan maka tujuan yang ingin dicapai sebagai berikut :

1. Untuk mengetahui pengaruh strategi bersaing terhadap kinerja perusahaan pada usaha jasa laundry di Labuhanbatu.

2. Untuk mengetahui pengaruh orientasi wirausaha terhadap kinerja perusahaan pada usaha jasa laundry di Labuhanbatu

3. Untuk mengetahui pengaruh strategi bersaing dan orientasi wirausaha terhadap terhadap kinerja perusahaan pada usaha jasa laundry di Labuhanbatu dengan lingkungan persaingan sebagai variable moderator.

\section{Strategi Bersaing (Competitive Strategy)}

Strategi merupakan alat bersaing yang perlu dimiliki oleh perusahaan dimana dalam penerapannya memerlukan perencanaan, pengkoordinasian, pengawasan serta pengevaluasian yang kuat dan akurat sehingga dapat menciptakan keunggulan bersaing bagi perusahaan. Penerapan strategi khususnya pada level bisnis merupakan pekerjaan yang memerlukan tantangan besar karena seringkali penerapan strategi bisnis ini tidak mampu mengimbangi pencapaian sasaran yang diharapkan. Penerapan strategi bisnis merupakan tugas penting bagi manajerial dalam mencapai kesuksesan organisasi. Tugas manajerial dalam menerapkan dan melaksanakan pilihan strategi ini memerlukan penilaian yang akan mengembangkan kebutuhan kemampuan organisasi dan pencapaian sasaran yang ditargetkan (Thompson dan Strickland, 2003). 
Pilihan strategi yang tepat akan menciptakan kinerja yang superior bagi organisasi. Pilihan strategi ini menjadi bagian yang perlu diperhatikan dalam penciptaan nilai bagi konsumen dan menghasilkan keunggulan kompetitif bagi perusahaan (Porter, 1980). Tipe strategi yang dipilih oleh perusahaan sebaiknya menyesuaikan dengan segala aktivitas dari setiap fungsi dalam organisasi. Penyesuaian pilihan strategi dengan setiap aktivitas fungsi dalam organisasi akan menciptakan keunggulan bersaing (competitive advantage) yang terlihat dari kinerja yang superior bagi perusahaan dan setiap tipe strategi yang dipilih oleh perusahaan sebaiknya memiliki keunikan dalam melayani pangsa pasar yang ditargetkan. Strategi yang dipilih juga memerlukan penyesuaian dengan setiap sumber daya internal khususnya yang berpengaruh pada manajemen sumber daya manusia yang unik karena sumber daya manusia merupakan bagian terpenting yang perlu diperhatikan oleh perusahaan sehingga dengan adanya kepuasan tenaga kerja yang dimiliki oleh perusahaan maka akan tercipta keunggulan bersaing bagi perusahaan

Porter (1980) menyatakan dua strategi bersaing generic adalah cost advantage dan differentiation. Cost advantage dicapai melalui reducing costs, dan differentiation meningkatkan profitabilitas dengan menyediakan peningkatan level service. Peningkatan level service disediakan melalui meng-capture order secara efisien, keberadaan produk, pengiriman yang tepat waktu, transparansi informasi dan meningkatkan respon. Porter (1985) menyatakan bahwa perusahaan harus memiliki strategy kompetitif yang jelas dengan tujuan untuk bersaing secara efektif dan memperoleh keunggulan kompetitif yang sustainable. Porter mengusulkan bahwa perusahaan dapat memilih menjadi penyedia produk dengan harga murah (cost efficiency strategy) atau penyedia produk yang unik dan inovatif (innovation strategy). Strategi bersaing merupakan pencarian posisi persaingan yang paling diharapkan oleh perusahaan terjadi di dalam industri (Porter, 1985). Strategi bersaing bertujuan untuk membangun keuntungan dan posisi bertahan yang berlawanan dengan kekuatan yang menentukan persaingan industri. Perbedaan setiap strategi bersaing yang digunakan perusahaan dalam arena persaingan dalam industri dapat menciptakan keunggulan 
bersaing.

Keunggulan bersaing merupakan dasar bagaimana perusahaan mampu menciptakan nilai untuk pembeli yang melebihi cost yang dikeluarkan perusahaan untuk penciptaan nilai tersebut (Porter, 1985). Nilai merupakan apa yang diinginkan oleh pembeli yang mempunyai keinginan untuk membayar, aliran penciptaan nilai yang superior yaitu bagaimana perusahaan menawarkan harga yang lebih rendah dari pesaingnya untuk mendapatkan manfaat yang sama atau memberikan manfaat yang unik dengan harga yang lebih tinggi. Dua dasar keunggulan bersaing ini adalah adanya cost leadership dan differentiation.

Tipologi organisasi menurut Miles \& Snow (1978) ini secara umum konsisten dengan pendekatan Porter. Miles dan Snow (1978) membedakan pilihan strategi ke dalam empat tipologi, yaitu: (1) prospector, (2) defender, (3) analyzer dan (4) reactor. Prospector adalah jenis perusahaan yang menggunakan strategi yang mementingkan pada inovasi, dan kreatitas untuk menciptakan produk baru. Perusahaan selalu berusaha untuk menjadi pioneer dalam bersaing, serta rela mengkompensasikan internal efisiensi dalam berinovasi dan berkreasi. Sementara kelompok defender selalu berusaha menciptakan strategi stabilitas dan kelangsungan hidup perusahaan. Fokus perusahaan adalah pada upaya pencapaian stabilitas jangka panjang dan mempertahankan inti bisnisnya (core business), tanpa banyak melakukan perubahan strategi.

Analyzer adalah kelompok perusahaan yang menggunakan kombinasi prospector dengan defender. Artinya perusahaan tidak berani ambil resiko dalam berinovasi, tetapi tetap berupaya menciptakan keunggulan dalam pelayanannya kepada pasar. Kelompok keempat adalah reactor yang selalu fokus pada efisiensi tanpa mempertimbangkan perubahan lingkungan yang terjadi. Reactor adalah tipe organisasi yang tidak memiliki konsistensi strategi dalam beradaptasi (unstable).

Menurut Smith, et al. (1989), tipologi strategi dari Miles dan Snow (1978) tersebut dapat mencerminkan kompleksitas lingkungan yang dihadapi organisasi dan proses organisasional dari berbagai dimensi, misalnya persaingan, perilaku konsumen, situasi dan respon pasar, teknologi, struktur organisasi dan karakteristik manajerial 
lainnya. Sementara orientasi teori strategi pada tipologi Porter (1980) hanya menggambarkan perilaku persaingan pasar secara umum.

\section{Orientasi Wirausaha}

Orientasi kewirausahaan memegang peranan penting dalam meningkatkan kinerja usaha. Menurut kamus bahasa Indonesia (2008) istilah "orientasi" didefinisikan sebagai: (1) peninjauan untuk menentukan sikap (arah, tempat, dsb) yang tepat dan benar; (2) pandangan yang mendasari pikiran, perhatian atau kecenderungan. Sedangkan wira berarti keberanian dan usaha berarti kegiatan bisnis yang komersial atau non-komersial Sehingga kewirausahaan dapat pula diartikan sebagai keberanian seseorang untuk melaksanakan suatu kegiatan bisnis. Wirausaha dinyatakan oleh Joseph Schumpeter yang dikutip oleh Buchari (2007:24) sebagai orang yang mendobrak sistem ekonomi yang ada dengan memperkenalkan barang dan jasa yang baru, dengan menciptakan bentuk organisasi baru atau mengolah bahan baku baru. Orang tersebut melakukan kegiatannya melalui organisasi bisnis yang baru ataupun yang telah ada. Dalam definisi tersebut ditekankan bahwa wirausaha adalah orang yang melihat adanya peluang kemudian menciptakan sebuah organisasi untuk memanfaatkan peluang tersebut. Dengan kata lain, wirausaha berarti manusia utama (unggul) dalam menghasilkan suatu pekerjaan bagi dirinya sendiri atau orang lain. Knight (2000) menjelaskan bahwa orientasi wirausaha berkaitan dengan pencarian peluang, keberanian mengambil resiko, dan keputusan untuk bertindak dari para pimpinan organisasi.

\section{Kinerja (Performance)}

Terdapat beberapa kriteria dalam menilai suatu kinerja perusahaan yang disampaikan dalam berbagai literatur. Kriteria tersebut meliputifinansial maupun non finansial. Kriteria- kriteria yang berbeda dalammengukur kinerja perusahaan tersebut sebenarnya bergantung padapengukuran kinerja itu sendiri. Tolok ukur bersifat unik, 
karena adanyakekhususan pada setiap badan usaha, antara lain bidang usaha, latarbelakang, status hukum, struktur permodalan, tingkat pertumbuhan dantingkat teknologi yang digunakan oleh perusahaan (Hatmoko, 2000).

Kinerja perusahaan dapat dilihat dari profitability, tingkat pengembalian investasi (ROI), pencapaian utamaperusahaan, pertumbuhan, inovasi, tingkat pengembalian asset (ROA/ROE) (Denison, et al.,1995). Profitabilitas dimaksudkan untuk mengetahui kemampuan perusahaan dalam menghasilkan laba dan untuk mengetahui seberapa jauh perusahaan dikelola secara efektif. (Dawes, 2000) menyatakan bahwa persepsi manajer atas profitabilitas perusahaan dapat menjadi pengukur kinerja yang baik. Harisis dan Ogbonna (2001); Bae Lawler (2001), menyatakan bahwa kinerja merupakan ukuran keberhasilan atau prestasi yang telahdicapai oleh suatu perusahaan yang diukur tiap kurun waktu tertentu. Kinerja perusahaan adalah pencapaian usaha sebagaimana tujuan perusahaan tersebut didirikan yaitu mendapatkan keuntungan sebesar-besarnya untuk dapat menopang pertumbuhan dan perkembangan.

\section{Lingkungan Persaingan}

Lingkungan persaingan adalah lingkungan dimana suatu perusahaan berada,beroperasi dan terlibat dan berkompetisi dengan perusahaan lain dalam industry yang sejenis (Arifin,1999). Kegagalan industri di dalam mencapai pertumbuhan penjualan bersumber dari ketidakmampuan manajemen dalam menganalisa perubahan yang terjadi di lingkungan persaingan industri (Mc Carthy dan Perreault, 1996). Yang termasuk dalam pendekatan lingkungan adalah hubungan yang dijalin perusahaan dalam lingkungannya dan partisipasinya dalam hubungan interpersonal jaringannya (Rothwell, 1991; dalam Hadjimanolis, 2000). Lingkungan bisnis selalu berubah, hal ini bisa terjadi karena perubahan peraturan, teknologi, permintaan konsumen, dan atau strategi berkompetisi (Calantone, 1994). Semakin besar derajad dinamika lingkungan, manajer semakin menghadapi alternatif-alternatif yang tidak jelas dan kriteria evaluasi lingkungan yang semakin sedikit (Venkatraman, 1989; dalam Luo, 1999). 
Lingkungan seringkali bersifat menantang dan kompleks Khasali (2010) menyatakan secara umum ancaman dari eksternal akan datang dari kompetitor, teknologi dan konsumen. Lingkungan eksternal memiliki dua bagian (Ireland dan Hoskinson, 1995) yakni lingkungan umum (elemen dalam masyarakat luas yang mempengaruhi industri dan perusahaan-perusahaan didalamnya) dan lingkungan industri (faktor ancaman masuknya peserta, pemasok, pembeli, produk pengganti dan intensitas persaingan yang mempengaruhi perusahaan dan tindakan serta tanggapan bersaing).

\section{Metode Penelitian}

Jenis penelitian ini menggunakan jenis penelitian Assosiatif. Lokasi penelitian ini adalah di Kabupaten Labuhanbatu. Populasi dalam penelitian ini adalah perusahaan laundry yang ada di labuhanbatu dengan teknik sampling yang digunakan adalah sampling jenuh. Jenis data yang digunakan dalam penelitian ini adalah data primer (kuesioner) dan sekunder (profil perusahaan). Skala instrumen penelitian yang digunakan dalam penelitian ini menggunakan skala Likert. Model yang akan digunakan dalam penelitian adalah model kausalitas atau hubungan atau pengaruh dan untuk menjawab rumusan masalah serta hipotesa yang diajukan, maka teknik analisis yang digunakan adalah analisis regresi linier berganda untuk menjawab rumusan masalah dan hipotesa nomor 1 dan 2, dan analisis model regresi moderasi untuk menjawab rumusan masalah dan hipotesa nomor 3.

\section{Pembahasan}

\section{Hasil Uji Validitas}

Hasil uji validitas terhadap item pertanyaan kuesioner secara keseluruhan dinyatakan valid, oleh karena probabilitas hasil korelasi lebih kecil dari 0,05 (5\%). Berdasarkan hasil pengujian yang ditunjukkan pada tabel di atas semua item adalah reliable karena memiliki nilai alpha cronbach di atas 0,6.

\section{Strategi Bersaing (X1) Terhadap Kinerja Perusahaan}


Dari penelitian yang telah dilakukan dapat disimpulkan bahwa hipotesis yang pertama "diduga ada pengaruh signifikan strategi bersaing terhadap kinerja perusahaan" dapat diterima. Hal ini sejalan dengan penelitian Menon, et al, (1999) marketing strategy making juga terbukti positif signifikan mempengaruhi kinerja pemasaran. Temuan penelitian ini relevan dengan hasil penelitian Khairinal (1997) yang menunjukkan bahwa Strategi Pemasaran berpengaruh terhadap ekspor produk perusahaan.

\section{Orientasi Wirausaha (X2) Terhadap Kinerja Pemasaran}

Dari penelitian yang telah dilakukan dapat disimpulkan bahwa hipotesis yang kedua “diduga ada pengaruh signifikan orientasi wirausaha terhadap kinerja perusahaan" dapat diterima. Penelitian ini memperkuat hasil penelitian Lee dan Tsang (2001) pada 168 UKM milik Cina di Singapura menunjukkan bahwa orientasi kewiraswastaan berpengaruh positif pada pertumbuhan dan kinerja bisnis. Namun tidak sejalan dengan Hart (1992, dalam Nasir dan Handoyo, 2003) yang menyatakan bahwa organisasi dengan tipe wirausaha adalah berhubungan dengan kinerja perusahaan yang rendah. Hasil penemuannya menunjukkan bahwa perusahaan yang para manajer puncaknya adalah wirausahawan ternyata lebih banyak yang kinerjanya rendah dibandingkan yang para manajer puncaknya bukan wirausahawan.

\section{Startegi Bersaing (X1) Terhadap Kinerja Perusahaan (Y) Dengan Lingkungan Persaingan (X3) Sebagai Moderator}

Dari penelitian yang telah dilakukan dapat disimpulkan bahwa hipotesis yang ketiga "diduga lingkungan persaingan sebagai variabel moderator mempengaruhi hubungan strategi bersaing terhadap kinerja perusahaan "ditolak. Ini berarti lingkungan persaingan bukan pemoderasi pengaruh strategi bersaing terhadap kinerja perusahaan. Hasil penelitian ini tidak sejalan dengan John E. Presscott (1986) yang telah melakukan penelitian tentang lingkungan bisnis sebagai moderator hubungan antara strategi dan kinerja yang hasilnya dipaparkan hubungan antara lingkungan, strategi dan kinerja bisnis merupakan perhatian sentral dalam manajemen strategik. Studinya menggunakan moderated regression dan analisis grup untuk menggali pengaruh moderasi lingkungan terhadap hubungan strategi dan kinerja. Hasil dari analisis regressi moderated menunjukkan bahwa variabel-variabel 
strategi berkontribusi sebesar $40 \%$ pada kovarian hubungan, sedangkan variabel lingkungan mempunyai kontribusi $2 \%$. Selanjutnya dikatakan lingkungan memoderasi variabel strategi yang secara signifikan berkaitan dengan Return on Investment.

\section{Kesimpulan dan Rekomendasi}

\section{Kesimpulan}

Berdasarkan hasil penelitian maka dapat disimpulkan hal hal sebagai berikut: (1) Hasil penelitian menunjukkan Strategi bersaing berpengaruh positif dan signifikan terhadap kinerja perusahaan pada perusahaan jasa laundry di Labuhanbatu. Hasil pengujian terhadap hipotesis 1 seperti yang telah dilakukan mengandung makna bahwa strategi bersaing sebagai variabel bebas memiliki pengaruh positif yang signifikan terhadap kinerja perusahaan sebagai variabel terikat. (2) Hasil penelitian menunjukkan orientasi wirausaha menunjukkan orientasi wirausaha berpengaruh positif dan signifikan terhadap kinerja perusahaan pada perusahaan jasa laundry di Labuhanbatu. Hasil pengujian terhadap hipotesis 2 seperti yang telah dilakukan mengandung makna bahwa orientasi wirausaha sebagai variabel bebas memiliki pengaruh positif yang signifikan terhadap kinerja perusahaan sebagai variabel terikat. (3) Hasil penelitian menunjukkan Lingkungan persaingan bukan sebagai moderating variabel mempengaruhi strategi bersaing dengan kinerja perusahaan pada perusahaan jasa laundry di Labuhanbatu.

\section{Rekomendasi}

Ada beberapa yang dapat dijadikan rekomendasi pada penelitian ini yaitu (1) Strategi bersaing yang tepat sangat diperlukan dalam meningkatkan kinerja perusahaan. (2) Untuk mendukung keberhasilan pelaksanaan strategi bersaing yang di susun, maka dibutuhkan kesiapan organisasi perusahaan dan pelaksanaannya. (3) Dalam rangka itu perlu dibuat kerangka organisasi yang jelas, efisien dan memuaskan bagi personalianya. (4) Selanjutnya personalia organisasi harus diseleksi dengan baik untuk mendapatkan tenaga yang benarhenar berkualitas, terampil dan mempunyai kemampuan. (5) Proaktifitas dalam segala hal menyangkut pemasaran produk merupakan satu hal yang tak kalah penting untuk dibangun 
oleh pihak manajemen. Salah satu bentuknya adalah dengan membuat terobosan cara pemasaran yang memiliki nilai tinggi dan berorientasi pada kinerja. (6) Manajer yang memiliki orientasi kewirausahaan kuat akan mengembangkan kemampuan berinovasi yang kuat dan menghasilkan kinerja bisnis yang tinggi. Kemampuan berinovasi diartikan sebagai kapasitas untuk mengembangkan produk baru yang dapat mengembangkan produk baru yang dapat memuaskan kebutuhan pasar, menerapkan proses-proses teknologi yang lebih sesuai untuk memproduksi produk-produk tersebut, mengembangkan dan mengadopsi produk baru dan teknologi pemorsesan untuk kebutuhan masa yang akan datang, serta merespon aktivitas teknologi yang tidak diduga serta kesempatan tak terduga yang diciptakan oleh pesaing.

\section{Daftar Pustaka}

Arifin. 1999 "Environmental Scanning and Strategic Planning'. Media Ekonomi dan Bisnis". Vol 11,N0 1-2 p.68-78.

Buchari Alma. 2007. Manajemen Pemasaran dan Pemasaran Jasa. CV Alvabeta: Bandung. Depdiknas, 2008, “Kamus Besar Bahasa Indonesia”, Gramedia Pustaka Indonesia.

Ferdinand, Augusty, 2002, "Marketing Strategy Making: Proses dan Agenda Penelitian”, Jurnal Sains Pemasaran Indonesia, Vol.1 No, 1, p. 1-22.

Hadjimanolis, Anthanasios (2000), An Investigation of Innovation Antecedent in Small Firms in The Context of ASmall Developing Country, Journal of R\&D Management, 30, 3, pp. 235-245.

Hitt, M.k Ireland, R.D., Hoskisson, R.E. 2001, Manajemen Strategis, Daya Saing dan Globalisasi; Konsep, terjemahan. Rimendi, R., penerbit Salemba Empat. Jakarta. Kanthadaraman P., Wilson DT, 2001. The Future of Competition: Value Creating Network, Industrial Marketing Management, 30, pp.379-390

Khairinal. 1997. Strategi pemasaran yang berpengaruh terhadap ekspor produk perusahaan industri furniture di daerah tingkat II Malang, Tesis. Malang: Program Pascasarjana Universitas Brawijaya

Knight, Gary, 2000, "Entrepreneurship and Marketing Strategy: the SME Under Globalization”, Journal of International Marketing, Vol.8, No.2, p.12 -32. 


\section{Jurnal Ecobisma Vol 5 No. 2 Juni 2018}

Menon, Anil, Sundar G. Bharadwaj, Phani Tej Adidam dan Steven W. Edison, 1999, "Antecedents and Concequences of Marketing Strategy Making : A Model and A Test”, Journal of Marketing, Vol. 63, p.18-40.Jurnal Administrasi Bisnis Volume I Nomor 1 September 2012.

Miles, R.E., Snow, C.C. ,1978. Organizational Strategy, Structure and Process, New York: Mc. Graw Hill Book Company

Porter, Michael E. 1980. Competitive Strategy - Techniques for Analyzing Industries and Competitors. The Free Press.

Porter, Michael E. 1985. Competitive Advantage - Creating and Sustaining SuperiorPerformance. The Free Press. 